\title{
Demand Fluctuations, Labour Flexibility and Productivity
}

\author{
Sangwon Park (Corresponding author) \\ Senior Lecturer \\ School of Hospitality and Tourism Management \\ University of Surrey \\ 53MS02 \\ Guildford, Surrey, GU2 7XH United Kingdom \\ Tel: 44(0)1483689660 \\ Fax: 44(0)148368 6346 \\ e-mail: sangwon.park@surrey.ac.uk \\ Natina Yaduma \\ Assistant Professor \\ Economics Discipline Area \\ American University of Nigeria \\ PMB 2250, Yola, Adamawa State, Nigeria \\ e-mail: natina.yaduma@aun.edu.ng
}

\author{
Andrew J Lockwood \\ Forte Professor of Management \\ School of Hospitality and Tourism Management \\ University of Surrey \\ 47MS02 \\ Guildford, Surrey, GU2 7XH United Kingdom \\ e-mail: a.lockwood@surrey.ac.uk
}

\author{
Allan Williams \\ Chair in Tourism and Mobility Studies \\ School of Hospitality and Tourism Management \\ University of Surrey \\ 46MS02 \\ Guildford, Surrey, GU2 7XH United Kingdom \\ e-mail: allan.williams@surrey.ac.uk
}




\title{
Demand Fluctuations, Labour Flexibility and Productivity
}

\begin{abstract}
There is a dearth of studies analysing the relationship between demand variations, productivity and flexible working in the face of variable demand challenges confronting the tourism industry. This investigation is needed to inform important firm and industry specific labour management strategies for improving productivity. Using data for 43 medium sized hotels owned by two chains in the UK, this paper analyses productivity in relation to external (demand variations) and internal (labour management) conditions over an 8 year period from 2005-2013. The paper's findings show that demand variation is the principal determinant of productivity. Numerical, functional and zero-contract hour flexible labour management also contributes to labour productivity. Significant differences in findings between establishment and departments indicate the importance of disaggregated analyses.
\end{abstract}

Keywords: Labour Productivity, Demand variations, Work flexibility, Economic Recession, Seasonality 


\section{Introduction}

Temporal demand fluctuations are a prominent feature in tourism (Andriotis, 2005; Highman \& Hitch, 2002), and assume various forms: for example, in particular seasons or days of the week, across the business cycle, or erratically. These pose major challenges in efficient resource utilization (Guizzardi \& Mazzocchi, 2010; Jang, 2004), especially labour (Butler, 1994; Capo, Riera \& Rossello, 2007). The challenges centre on the well-known tourism issues of perishability, the impossibility of inventorying unsold services (Baker \& Riley, 1994), and economies of scale in staffing. Previous researchers have addressed the impact of demand variations on local economies (typically employment) and environments (Butler, 1994; Koenig-Lewis \& Bischoff, 2005) but there has been surprisingly little investigation of the relationship between demand and productivity, and the effectiveness of labour flexibility in responding to this challenge.

While responding to different forms of demand variations has always been a major influence on productivity in tourism, and specifically for hotels, (Morikawa, 2012), this has become even more important in the face of the globalization of competition, and global recession. Following the 2008+ economic crisis, Gross Domestic Product (GDP) per capita declined globally by $3.4 \%$ in 2009 , and by $4.7 \%$ in the EU-27 (Eugenio-Martin \& CamposSoria, 2014), with implications for disposable incomes and business expenditure, as well as for investment in operations and properties (Smeral, 2010). It is a question not only of their occupancy levels and effective capacity utilisation, (Boffa \& Succurro, 2012; Jeffrey \& Barden, 2001), but also of managing the most significant input cost, labour.

Establishments may respond to these challenges by either managing the level of demand, or through 'chase demand management' which manages inputs in response to these variations (Jones \& Robinson 2012). Demand management typically includes optimal pricing strategies (Pan, 2007). However, given the labour intensive nature of most tourism operations, 
chase management strategies are also important, especially effective labour force utilisation involving flexible working. It is not only a question of flexibility in the hours of labour scheduled, but also of ensuring the available workforce delivers quality services and experiences, which are integral to service productivity (Blake, Sinclair, \& Soria, 2006; Hu \& Cai, 2004). This raises the issue of the effectiveness of different forms of flexible working (Kelliher 1989; Lockwood \& Guerrier 1989), but the impacts on productivity at the micro level, although gaining the attention of academics and policy makers (Koenig-Lewis \& Bischoff, 2005), remain substantially under-researched.

This paper aims to fill this gap by analysing labour productivity in the hotel sector in relation to both external (demand variations) and internal (labour management) conditions (Sigala, 2004). Specifically, this study analyses labour productivity in two UK hotel chains which manage 25 and 18 hotels, respectively. Controlling for heterogeneity, by focussing on only two chains, is important because labour management practices are likely to be firm specific. The panel data set, provided by the management systems company Eproductive, allows analysis of financial performance and labour management practices at the establishment and departmental (rooms versus food and beverage $[\mathrm{F} \& \mathrm{~B}]$ ) levels that account for most hotel operations (Brown \& Dev 2000; McMahon, 1994; Wong, 2004), and more than $90 \%$ of total average revenue in this case study. It consists of monthly series for an 8 year period, 2005 to 2013, covering the recent $2008+$ economic recession. This research provides theoretical contributions to the literature about the tourism economy by identifying the dominant influences of demand variation, together with flexible labour management, on service productivity. Importantly, the findings of this study highlight the heterogeneity of productivity across chains, firms and departments.

The theoretical background, including demand variations, productivity and labour flexibility, is discussed in the next section, followed by a third section which discusses the 
methodology. The fourth section of the paper presents the findings, and the implications, while the academic and managerial implications are discussed in the final section of the paper.

\section{Literature review}

Productivity is a function of external and internal factors (Sigala, 2004). Variable demand conditions, usually the most important external feature, are discussed below while internal labour management is discussed in the following section.

\section{Demand variations and productivity in tourism and hospitality}

Different forms of temporal variations exist in hotel operations, including erratic, diurnal and weekly (Kimes, 2004) but this paper focusses on seasonal fluctuations and business cycles (Butler, 1994; Jang, 2004). Seasonality effects are pervasive and assume different forms in particular destinations (Nadal, Font, \& Rossello, 2004), while the 'normal' business cycle effects have been starkly evident in the 2008+ global economic crisis (Smeral, 2010).

Seasonal demand variations are shaped by natural and institutionalised factors (BarOn, 1975). Natural factors refer to environmental phenomena with climatic changes being particularly important in destinations relying on outdoor activities. Institutionalised seasonality refers to temporal variations resulting from regulatory frameworks and customary behavioural patterns (Butler, 1994): for example, public holidays, school schedules, and historic, religious and cultural events. Business travel also fluctuates both across the month, and the year, with conferences and exhibitions being strongly seasonal. In addition, social pressures (or fashion), sporting seasons and traditional behaviour (or inertia) also influence demand variations (Baum, 1998; Butler, 1994; Highman \& Hitch, 2002).

There are both demand and supply side analyses of the determinants of temporal variations in expenditures. Demand side studies focus on macro-economic elements, such as 
income elasticity, relative price, and exchange rates (Nadal, et al., 2004) and economic cycles (Guizzardi \& Mazzocchi, 2010; Smeral, 2010), and individual characteristics including tourism motivations (Spotts \& Mahoney, 1993) and information search strategy (Boffa \& Succurro, 2012). Supply side studies focus mostly on the facilities and attractions that influence effective demand (Koening-Lewis \& Bischoff, 2004). Capò Parrilla, Font, and Nadal (2007) demonstrated that the service quality and locations of hotels influence demand variations (see also Barros, 2005).

Much of the research on seasonality has focussed on capacity and fixed costs. During off-peak periods, tourism and hospitality businesses typically suffer sharp reductions in revenues and returns on investment due to under-utilized capacity and constant fixed costs of operations (Bar-On, 1999; Cuccia \& Rizzo, 2011). Hence, organisations need to earn sufficient revenues during peak seasons to sustain the business during all year round. Whereas too little demand is a problem in the off-peak season, high levels of peak season demand pose challenges in maintaining service quality, meeting consumer expectations, and guest satisfaction, all of which impact on firm performance (Capò Parrilla, et al., 2007). Seasonality can have positive impacts, allowing businesses to undertake maintenance/refurbishment work that improves guest experiences, or provide opportunities to develop new markets (Grant, Human, \& Le Pelley, 1997), thereby contributing to long-term productivity. However, the greatest challenge posed by seasonality for productivity in most firms is managing staffing levels (Ball 1989; Jolliffe \& Farnsworth, 2003; Krakover, 2000). Labour flexibility, discussed in the next section, is a common response to this challenge.

In addition, firms also face demand variations across the business cycle. This has been particularly significant since the global economic crisis, originating from the USA in 2007, subsequently spreading to Europe and the rest of the world by 2008 , is followed by uneven and hesitant recovery. Increased unemployment, reduced disposable incomes, and greater job 
insecurity are expected to depress discretionary consumer spending on tourism (Sheldon \& Dwyer, 2010; Smeral, 2010). Declining asset prices and capital also attenuated the ability of businesses to fund debt or to invest in, say innovations (Papatheodorou, Rossello, \& Xiao, 2010), with implications for productivity levels. The demand impacts varied across market segments (Sheldon \& Dwyer, 2010; Smeral, 2009) with, for example, long haul travel declining more than short haul travelling (Bronner \& de Hoog, 2011) due to price differentials, and individual consumers seeking to reduce the risks associated with quality (Page, Song \& Wu, 2012; Smeral, 2010). Tourists also focussed more on reducing total spending and seeking discounted prices (European Travel Commission 2013).

The effects of the recession on demand have been analysed at the macro (Smeral, 2010; Song, Lin, Witt, \& Zhang 2011) and micro levels (Eugenio-Martin \& Campos-Soria, 2014). However, there has been little research on variations in labour productivity in service industries generally (Morikawa, 2012), let alone tourism and hospitality. The UK, and much of Europe, has seen a 'productivity puzzle' in the $2008+$ crisis (Oulton \& Barriel, 2013). In the UK, while economic output began to recover following second quarter of 2009 , unlike in previous recessions, labour productivity showed few signs of recovery in either the general economy or in accommodation services.

Jones and Robinson (2012) identify two broad strategies that firms adopt in responding to variable demand conditions: demand management and chase demand strategies. In terms of demand management, revenue management seeks the optimal trade-off between average daily room price and occupancy rate which maximizes revenues. RevPAR is the most frequently used indicator, as outlined in Research Design. Dynamic pricing strategies offer different room rates depending on changes in the unsold inventory (Pan, 2007). For example, discounted pricing can mitigate seasonal effects by generating demand, including contra-seasonal pricing (Butler \& Mayo, 1996; Jang, 2004). Although such strategies are essential in meeting the 
productivity challenge, they lie outside the scope of this paper which instead focuses on chase demand strategies, especially flexible working.

Variable demand conditions and labour flexibility in the tourism and hospitality industry

The most influential internal factors related to productivity include the number of fulltime workers (Brown \& Dev, 2000; Hu \& Cai, 2004), working hours (Johns, Howcroft, \& Drake, 1997), labour flexibility (Baker \& Riley, 1994; Kappa, Nitschke, \& Schappert, 1997), labour costs (Sigala, 2004), and human resource practices (Kilic \& Okumus, 2005; Witt \& Witt, 1989). The effectiveness of labour management in response to variable demand conditions and the highly perishable nature of the services provided (Sigala, 2004) is complex. When demand is low, capacity is underutilized in the face of significant fixed costs, such as minimum staffing levels, with negative effects on productivity (Fernandez-Morales \& Mayorga-Toledano, 2008). On the other hand, when demand exceeds capacity, there may be negative effects on quality, potentially decreasing productivity (Capò Parrilla et al., 2007; Gronroos \& Ojasalo, 2004).

Flexibility is central to how tourism firms respond to variable, and uncertain, demand conditions (Bagguley, 1990). The most comprehensive generic research on the relationship between management and productivity (Bloom and van Reenen 2007, 2010) demonstrates a statistically significant relationship between flexibility and several performance measures. There are different forms of flexibility in hotel operations (Sethi \& Sethi 1990). However, this paper focuses on work, or labour flexibility (Dreyer \& Grønhaug 2004), particularly Atkinson’s classic (1984) distinction between numerical flexibility (volume changes) and functional flexibility (redistribution between tasks and departments).

Numerical flexibility involves utilising variable amounts of labour either within the existing workforce, or from sources external to the firm, such as agencies or other temporary 
employees (Boockmann \& Hagen, 2001). External workers incur additional labour costs to firms when hired at peak times, but their hourly costs tend to be higher in compensation for uncertain working conditions, and they may lack firm-specific skills. In recent years, there has been growth of a specific form of numerical flexibility, the employment of 'permanent' or internal workers and zero-hours contracts; this allows firms to retain workers with firm-specific skills, while providing flexibility to reduce costs when demand is low (Berg et al, 2014). Functional flexibility involves internal transfers of workers between departments or tasks in response to the uneven distribution of demand across the firm (Hempell \& Zwick, 2005). The impact of functional flexibility on productivity depends on wage cost differentials between departments, and the specificity of departmental skill requirements. Hotels tend to utilise a mix of numerical and functional flexibility, seeking 'flexibility from both sides' (White et al., 2004: 440).

Given the importance of work flexibility in tourism and hospitality, these practices have not been well documented. On the one hand, Lockwood and Guerrier (1989) found that numerical flexibility was more important than functional flexibility in major UK hotel chains. This was broadly confirmed by Nickson (2010) who demonstrated that functional flexibility mainly provided short term labour cover. However, these researchers, as well as Warhurst and Nickson (2007), found that both types of flexible working were characteristic of hotel employment.

The impact of different forms of flexibility on productivity depends on the skill requirements of the tasks undertaken, and whether these are generic, firm or department specific. Productivity is also influenced by the differential wages of different categories of workers across departments and the effectiveness of labour scheduling. The relationship between labour flexibility and productivity is under-researched but, as noted earlier, Bloom and van Reenen's (2007) generic research evidences a strong association between firm 
performance and flexible working. However, they did not examine the individual components of flexible working, a major limitation given these can have contradictory outcomes on performance. Empirical estimates of these effects have been relatively inconclusive. Some researchers have found that numerical flexibility is negatively associated, and functional flexibility is positively associated with enhanced performance (Michie \& Sheehan, 2001, 2005; Chadwick \& Cappelli, 2002). However, other researchers found no evidence of a relationship between numerical flexibility and labour productivity (Bryson, 2007; Kleinknecht et al., 2006). The mixed evidence partly reflects the heterogeneity of some samples, because these effects can be highly sector, firm, and task specific (Gustavsson, 1984). Therefore, the paucity of research on the relationship between flexibility and productivity in tourism and hospitality is a significant lacuna. Although Li and Prescott (2010) found a positive association between internal numerical flexibility and productivity in Canadian tourism firms, other researchers have faced severe data constraints when seeking to operationalise their models (Baker \& Riley, 1994; Kappa et al., 1997; Soltani \& Wilkinson, 2010). This underlines our paper's contribution given access to a highly disaggregated hotel panel data-set.

Other variables related to labour productivity: training, numbers of employees and gender

As a labour intensive industry, the skill levels of labour are expected to exert varying effects on performance in hotels. This creates room for staff training to improve employee skillsets (Reynolds \& Biel 2007). Tourism businesses may spend a considerable portion of their budgets on training programmes to enable staff obtain multiple-skills, although this also tends to be variable. Training can improve the multi-tasking skills of employees, hence facilitating the movement of workers across departments. This could be particularly important in meeting temporary labour shortages in departments, and, could also improve productivity (Kilic, \& Okumus, 2005; Morita, 2005). 
From the cost saving perspective, under-utilized capacity is an inhibitor of labour productivity. Of particular importance here is the level of staffing, and particularly the issue of overstaffing (Sill, 1991). Lockwood and Bowen (2004) emphasized the importance of (labour) cost reduction as a means to increase net revenue. That is, scheduling the appropriate number of employees, with the required skills, at the appropriate time each day on the basis of demand forecasting is the key issue. This contrasts with increasing the number of staff in a way which creates overspending or labour under-utilization (Sigala, 2004). The marginal effect of the workforce size can be captured through the number of employees.

Gender is another characteristic of the labour force that has been researched by labour economists as a determinant of productivity differences. Whereas, this was traditionally considered indirectly via the analysis of wage equations, more recent researchers have provided direct estimates of gender effects in production functions (Bloom \& van Reenen, 2010). For example, Hellerstein et al (1999) found that the lower relative earnings of women were not associated with lower relative marginal products. The highly gendered nature of employment in hospitality in general is well documented (Adib \& Guerrier 2003), with Bagguley (1990) noting that women were more likely to be numerically functional (particularly, in being part time) and less likely to be functionally flexible than men. There are, however, no estimates of how gender influences productivity, whether this is due to differences in attitudes and skills, or wages. Moreover, any such effects are likely to be heterogeneous, both across time and firms/establishments.

Figure 1 provides an overview of the paper's approach to labour productivity relationships.

[Insert Figure 1 here]

\section{Research design}




\section{Data collection}

Data were obtained from Eproductive, a London based management systems company, which provides software to client hotels to record data on a period basis: for all workers on an hourly basis, and output data as daily summaries. These are converted to calendar month data. The sample covers two medium sized UK hotel chains, providing panels of 25 and 18 hotels for the first and second chains, respectively; average establishment size (rooms and employment) is larger in chain 2 than in chain 1. Data for the former and latter chains span from 2005:M7 to 2013:M12 and 2007:M3-2013:M12, respectively. The chains are assessed separately in order to investigate inter-firm differences in the effectiveness of their labour management.

The analysis is undertaken not only at establishment (i.e., overall rooms and F\&B as well as residual departments) but also covers two core departments - rooms and F\&B - in order to address aggregation bias (Higon et al., 2010) and identify heterogeneity in management practices. Table 1 presents an overview of constitutive departments of the establishment, rooms and F\&B departments.

\section{[Insert Table 1 here]}

\section{Measuring productivity}

This paper examines labour productivity rather than total factor productivity as data is not available on either capital or technology. This is a useful approach because of the labourintensive feature of hotels (Mill, 2008; Rust \& Huang, 2012) and our focus on labour flexibility in response to demand variations. Labour productivity is also appropriate because the widespread separation of the ownership of assets and hotel operations blurs the relationship with capital inputs, while technology is assumed to be relatively invariant within firms (Rust \& Huang, 2012). 
Productivity is defined as gross revenue per hour of labour input (OECD 2001). This is informed by Gronroos and Ojasalo's (2004) recommendation that financial measures (rather than physical measures) are the most theoretically relevant approach to measuring productivity in services, given that prices reflect perceived service quality in a competitive market. Labour productivity is defined as the ratio of total revenues from room nights, F\&B sales, conference and banqueting, leisure etc to total labour hours at the establishment. Analogous measures apply to the core departments- rooms and F\&B.

\section{Method}

Descriptive and inferential statistical methods are employed in assessing changes in hotel productivity in the face of seasonal and cyclical variations in demand for hotel services covering the entire scope period, and the pre-crisis, crisis and post-crisis periods. Summary descriptive statistics are followed by stepwise and panel econometric models - fixed and random effects estimators - to investigate the relationship between productivity, labour management strategies, prices and occupancy rates. The estimations commence with a stepwise model where the regression procedure successfully adds explanatory variables whose p-values are statistically significant at the 15 percent level (Wooldridge, 2008). The goal of employing the stepwise procedure before estimating fixed and random effects models is to explore how much variation in productivity is explained by its most significant determinant, and to identify the additional variation explained by other significant determinants. To ascertain this variation in productivity, a two-step fixed or random effects model is estimated: first, productivity is regressed on its most significant regressor to give an estimate of the variation in productivity explained by this regressor; second, productivity is regressed on its full set of significant regressors. Coefficients of determination provide estimates of variation in productivity attributable to the most significant regressor and the additional variation attributable to other significant regressors, respectively. The models are subjected to the Hausman test (Hausman, 
1978) in choosing the appropriate estimator - fixed or random effects estimator. This research focuses on interpreting the results produced by step 2 instead of the stepwise results as the latter estimation procedure does not control for time constant unobservable variables. Hence, results from fixed and random effects estimations are less likely to lead to estimation bias relative to pooled OLS estimation implemented by stepwise regression.

The stepwise search for the most appropriate variables employs the model:

$$
\begin{aligned}
& \operatorname{lnprod}_{i, t}=\mu_{i}+\beta_{1} \ln \text { numflex }{ }_{i t}+\beta_{2} \operatorname{lnfuncfle} x_{i t}+ \\
& \left.\beta_{3} \ln \text { shareofzerohours (shareofpermhours) }\right)_{i t}+ \\
& \beta_{4} \ln \text { shareoffemalehours (shareofmalehours) }{ }_{i t}+\beta_{5} \ln \text { trainingcost } t_{i t}+ \\
& \beta_{6} \operatorname{lnRevPAR} R_{i t}+\beta_{7} \text { numofemployees }_{i t}+\beta^{\prime} \text { monthdummiess }{ }_{i j t}+\varepsilon_{i, t} \text {, } \\
& i=1, \ldots, 25(1, \ldots, 18) \text { and } t=2005 M 7-2013: M 12(2007: M 3-2013: M 12)
\end{aligned}
$$

$i$ and $t$ in the equation represent the cross-sectional units, individual hotels, and time periods respectively; the prefix to variables $l n$ denotes natural logarithms of variables. All continuous variables in the model are logged to obtain a constant elasticity interpretation of the effect of the independent on the dependent variables; prod is labour productivity defined as the ratio of financial output - actual revenues (or total sales from establishment, rooms or $\mathrm{F} \& \mathrm{~B}$ departments) - to labour hours. $\mu_{i}$ is the unobserved hotel specific time invariant effect; $\beta_{1}$ to $\beta_{19}$ are slope parameters to be estimated (with $\beta$ ' denoting a vector of coefficients, $\beta_{8}$ to $\beta_{19}$, for monthly binary variables); $\varepsilon_{i, t}$ is a random error term. Proxies for other explanatory variables are explained below.

i. Numerical Flexibility (numflex) measures the extent an employee is numerically flexible on a monthly basis relative to their average monthly hours, aggregated over all employees and dividing by the number of employees. This is computed as: $\Sigma\left[\left(\mathrm{x}_{\mathrm{i}^{-}}\right.\right.$ $\left.\left.\mu_{\mathrm{i}}\right) / \mu_{\mathrm{i}}\right] / \mathrm{n}$, where $\mathrm{x}_{\mathrm{i}}, \mu_{\mathrm{i}}$ and $\mathrm{n}$ stand for an employee's monthly working hours, yearly 
average monthly working hours and number of employees in the sample, respectively.

ii. Another measure of numerical flex, shareofzerohours, is the share of zero-contract employee hours to total hours by all staff. An analogous measure applies to share of permanent-contract hours, shareofpermhours.

iii. Functional Flexibility (funcflex). At the establishment level, this is the ratio of hours of inter-departmental employee transfers across all micro-departments in the hotel to total employee hours. For rooms departments, this is defined as the ratio of hours of employee imports from all other departments to total hours in the rooms departments. An analogous index is computed for food and beverage departments. An index close to zero denotes a low level of inter-departmental employee transfers, hence flexibility.

iv. Female (shareoffemalehours) and Male (shareofmalehours) Labour: The share of female (male) hours to total hours by all workers in the establishment and two core departments controls for gender employment. Assuming an optimal number of employees and working hours, increasing the share of female hours inevitably implies decreasing the share of male hours. To control for this potential source of collinearity presuming both variables make it through the second stage of the estimation, one of the shares, for instance female, is entered first and the model estimated. This is then substituted with the share of male hours and the same model is re-estimated. The same procedure applies to the shares of zero and permanentcontract hours.

v. Training Cost: Total monthly expenditures on training programmes in the establishment, and departments, proxies for staff training. 
vi. Revenue Per Available Room $(\operatorname{RevPAR})$ is measured as the product of mean room rate with occupancy, and is a key performance indicator of the efficiency of hotels in using demand management to fill rooms. It is considered in this study to reflect demand variations in the establishment and rooms department. An analogous measure for $\mathrm{F} \& \mathrm{~B}$ department is based on occupancy rate and price of $\mathrm{F} \& \mathrm{~B}$ covers (Anderson, Fish, Xia, \& Michello, 1999; Baker \& Riley, 1995).

vii. Number of employees is the employee count recorded in the hotels' and departments' schedules without double counting. The coefficient captures the marginal effect of the size of the workforce on productivity.

viii. Monthly Dummies: Demand for hotel services is expected to follow seasonal patterns. Productivity, RevPAR and other regressors may also exhibit seasonal patterns. Month dummies account for seasonality in both dependent and independent variables (Wooldridge, 2008). We define 11 monthly binary variables to control for seasonality. The base period is January, and the coefficients of the other 11 monthly dummies are intercepts capturing the differential in productivity between the base and other months. The significance of the month dummies are jointly considered in the stepwise regression, capturing differential in average productivity between the base and other months. Coefficients of these variables are not reported in the final results as they are constants controlling for seasonal variation in productivity and other regressors. Estimates of these constants would be informative in obtaining monthly projections of productivity, but our analysis concentrates on estimating the relationships between productivity and labour management variables instead of predicting future values of productivity.

\section{Results}




\section{The descriptive analysis}

Table 2 provides summary statistics (means) of the variables. The mean productivity in the establishment implies that one labour hour produces $£ 22.16$ and $£ 27.88$ of output in chains 1 and 2, respectively. Room prices and occupancy rates are higher in Chain 2 relative to Chain 1. Both chains record similar levels of numerical and functional flexibility at the establishment and departmental levels. Hourly labour costs for zero-contract employees are less than those for permanent-contract staff in both chains. Furthermore, hourly wage costs for females are slightly less than those for males in both chains. The table also contains summary statistics for other relevant variables.

[Insert Table 2 here]

\section{Understanding demand variations in hotels}

Demand for hotel services in the UK is manifested through several forms of temporal variation, but this paper focuses on seasonal and cyclical patterns.

Seasonal Patterns: Demand for hotel services typically displays a recurring seasonal pattern, reflecting natural and institutional factors. The seasonal patterns in productivity and occupancy for chains 1 and 2 are closely related (Figures $2 a$ and $2 b$ ). These generally are at their minimum in late winter, January to February, then slowly rise over time. They peak in May to September primarily due to a combination of high business (including conference) and leisure demand months (Jeffrey \& Barden, 2001). This is followed by a slow decline in late autumn and early winter, October to December. However, productivity rises starkly between November and December, mostly due to a sharp increase in food and beverage sales for end of year celebrations (e.g., Christmas parties). There is a general increase in mean food and beverage sales of 45 percent and 38 percent from November to December in chains 1 and 2 respectively. 
Hence, demand for hotel services, measured by occupancy rates (or RevPAR) and productivity, have clear seasonal patterns.

[Insert Figures $2 \mathrm{a}$ and $2 \mathrm{~b}$ here]

Mean monthly room prices in the two chains follow a similar pattern from March to December with peaks in June and September (Figure 3), mainly attributable to peaks in the joint leisure and business demand for hotel services

[Insert Figure 3 here]

Cyclical Pattern: A second expected component of variation in demand arises from long-term cyclical fluctuations. Figure 4 presents mean productivity, and Figure 5 shows occupancy rate, with the GDP growth rate from 2005 to 2013. The graphs depict a generally declining trend in productivity and occupancy rate overtime. Unlike the seasonal patterns analysed above, these variables do not exhibit clear cyclical patterns. The variables show no clear correlations with GDP growth rate, and the inclusion of one and two period lag and lead variables of occupancy rate and productivity still does not identify any consistent relationship with GDP. This implies that these hotels may not follow the overall macroeconomic cycle but follow industry or firm-specific cycles.

There is divergence between the two chains' mean productivity, occupancy rates and room prices in the economic crisis period $(2008+$ economic crisis and economic dips in 2011:Q3 and 2012:Q2) relative to the non-crisis period. Chain 1 generally records higher productivity, occupancy rate and room prices in the non-crisis than the crisis period $-£ 22.18$, 0.608 and $£ 53.20$ relative to $£ 22.09,0.585$ and $£ 54.83$ respectively. The reverse applies in the 
second chain: productivity, occupancy rate and room prices of $£ 27.62,0.654$ and $£ 61.46$ in the non-crisis period relative to $£ 28.62,0.673$ and $£ 63.56$ in the crisis period respectively.

[Insert Figure 4, 5, and 6 here]

\section{Econometric Results}

The first and second step estimations from fixed and random effects models for establishment, rooms and F\&B departments are shown in Tables 3, 4 and 5. Coefficient estimates at the left and right hand sides of the tables correspond to results for chains 1 and 2 , respectively. The upper half contains results for the first step with the most significant predictor of labour productivity as the only regressor. The lower half contains results for the joint set of significant predictors of productivity identified by the stepwise estimation. Standard errors of parameter estimates are reported in parentheses next to estimated coefficients. The Hausman specification test considers the fixed effects estimator to be more appropriate than random effects in all models. Moreover, panel unit root test confirm series used for the estimation are stationary. Hence, the tables present fixed effects estimations. It is worth noting that the F-test of joint significance of the hotel fixed effects also informs that fixed effects is more appropriate than pooled OLS estimation in all models considered. RevPAR and month dummies consistently make it through the stepwise variable adding process as significant regressors in establishments and rooms departments. In addition to occupancy rate and room price, the month dummies are also significant in the stepwise estimations for F\&B department. Tests for multlicollinearity in the right-hand-side variables of estimated models, using the variance inflation factor, tolerance, correlation tests, and the variable substitution procedure suggest multlicollinearity is not an issue in the estimations (results for these tests available on demand). 


\section{$\underline{\text { Establishments }}$}

\section{Chain 1}

Stepwise regression identifies RevPAR as the most significant, hence most important, predictor of productivity in chain 1 , with $\mathrm{R}^{2}$ in the first step accounting for roughly 73 percent of the variation in productivity (Table 3). Moving to the model with the complete set of significant predictors of productivity in step two, RevPAR has a positive association with productivity. A one percent increase in RevPAR leads to a 0.81 percent increase in productivity. Numerical flexibility, functional flexibility and share of zero-contract hours also have positive associations with productivity. A one percent increase in these variables is associated with $0.23,0.03$, and 0.02 percent increases in productivity, respectively. However, permanent-contract labour (when modelled instead of share of zero-contract hours) and the number of employees exert negative effects on productivity. A one percent increase in these variables leads to a 0.36 and 0.57 percent decrease in productivity respectively. The $\mathrm{R}^{2}$ statistic denotes that the joint set of regressors account for 83 percent of the variation in productivity, and the F-statistic indicates the regressors are jointly significant.

\section{Chain 2}

Results for chain 2 are similar to the first chain. Again, as indicated by the $\mathrm{R}^{2}$ in the first step in Table 3, RevPAR alone accounts for approximately 68 percent of the variation in productivity. From the second step model, a one percent increase in this variable is associated with a 0.89 percent increase in productivity. Also, a one percent increase in numerical flexibility, zero-contract hours and number of employees is associated with 0.04 and 0.03 percent increases, and a 0.64 percent decrease, in productivity respectively. The entire set of regressors in step 2 account for 89 percent of the variation in productivity. This implies labour 
management variables explain roughly 21 percent of this variation. The F-statistic denotes the regressors are jointly significant.

\section{[Insert Table 3 here]}

\section{$\underline{\text { Rooms Departments }}$}

\section{Chain 1}

RevPAR is the most significant predictor of productivity in chain 1's rooms department in the first step (see Table 4). This variable alone explains roughly 80 percent of the variation in productivity, an additional 7 percent more than that explained at the establishment. This result is unsurprising as RevPAR is directly geared at measuring performance in rooms departments. Results in the second step indicate that a one percent increase in RevPAR and functional flexibility exerts a 0.87 and 0.01 percent increase in productivity, respectively. Increasing the share of permanent-contract labour and number of employees by one percent leads to a 0.29 and 0.42 percent decrease in productivity, respectively. An $\mathrm{R}^{2}$ of 87 percent denotes that labour management variables jointly account for a modest variation in productivity after factoring out the proportion of variation explained by RevPAR. Again, the F-statistic denotes the regressors are jointly significant.

\section{Chain 2}

As in chain 1, RevPAR explains approximately 80 percent of the variation in productivity in rooms, and is greater than for establishments. Results from the second step show that a one percent increase in RevPAR exerts a 0.87 percent increase on productivity. This variable's marginal effects on rooms productivity in both chains are roughly similar. These effects are larger than for the establishments. Other results for this chain's rooms 
department show that a one percent increase in numerical flex is associated with a 0.10 percent increase in productivity. The shares of female and male labour exert diverging effects on productivity. A one percent increase in the former and latter variables is associated with a 0.11 percent increase and 0.07 percent decrease in productivity, respectively. This result is partly explained by the lower hourly wages of female labour (see Table 2). Again, the number of employees has a negative influence on labour productivity. An $\mathrm{R}^{2}$ of 0.93 implies labour management variables account for roughly 13 percent of variation in productivity after controlling for the variation explained by RevPAR. The F-statistic denotes the regressors are jointly significant (see Table 4).

[Insert Table 4 here]

\section{$\underline{\text { Food and Beverage Department }}$}

Chain 1

RevPAR is substituted with occupancy rate (surrogate for numbers of potential customers) and price of $\mathrm{F} \& \mathrm{~B}$ covers for the analysis in $\mathrm{F} \& \mathrm{~B}$ department. The results for the first chain in step one shows that the occupancy rate is the most significant determinant of productivity (see Table 5). Occupancy rate and the average price of $F \& B$ covers explain approximately 58 percent of the variation in productivity. From the second step, a one percent increase in occupancy rate leads to a 0.83 percent increase in productivity. This high marginal effect implies that occupancy rate (a constituent of RevPAR) is also an important predictor of productivity in $\mathrm{F} \& \mathrm{~B}$ departments. As expected, F\&B sales is positively associated with the number of guests in the hotel. A one percent increase in average $F \& B$ spend, zero-contract labour and training costs exert $0.12,0.02$ and 0.01 percent increases in productivity, respectively. However, a one percent increase in share of permanent-contract employees and 
number of employees is associated with productivity decreases of 0.12 and 0.37 percent respectively. These results further amplify the effects of higher hourly wages earned by permanent relative to zero-contract workers, and the diminishing marginal product of recruiting an extra employee. An $\mathrm{R}^{2}$ of 71 percent in the second step implies that the labour management variables account for roughly 13 percent of the variation in productivity.

\section{Chain 2}

In chain 2 , occupancy rate and the price of $F \& B$ covers are the most significant determinants of $\mathrm{F} \& \mathrm{~B}$ productivity, accounting for approximately 73 pecent of the variation in productivity. The latter variable tops occupancy rate in the stepwise ordering of significant predictors of productivity. Results from the second step estimation show that a one percent increase in occupancy rate, $F \& B$ spend and numerical flexibility is associated with $0.75,0.68$ and 0.23 percent increases in productivity, respectively. The marginal effect of $F \& B$ spend is considerably larger than in chain $1-0.68$ relative to 0.12 . In contrast to the findings in chain 1's establishment, rooms and F\&B departments, permanent-contract labour exerts a positive effect on productivity in this chain's F\&B department. A one percent increase in permanentcontract hours leads to a 0.09 percent increase in productivity. An $\mathrm{R}^{2}$ of 76 percent in step 2 denotes labour management variables account for only a modest increase in productivity variation after taking into account occupancy rate and F\&B price. The F-statistic indicates the regressors are jointly significant.

[Insert Table 5 here]

\section{Discussion}


The productivity challenge faced by the two chains appears to be largely independent of the major economic crises of the last decade. Occupancy, productivity and revenue (Figures 2-4) do not seem to follow macroeconomic performance as measured by GDP growth (see Smeral, 2010). The same conclusion applies if time lag and lead variables are considered. The fact that occupancy levels did not plunge after the onset of the economic crisis may reflect a substitution effect: these are largely three star, middle market, chains which may have benefitted from customers trading down from higher priced chains (see also Deloitte, 2009, on the USA). However, more difficult operating conditions may have contributed to an inability to raise room rates post 2008 (Figure 6), so that productivity levels have largely stagnated (Figure 4). Oulton and Barriel's (2013) productivity puzzle - the failure of productivity to grow after the depths of the $2008+$ crisis - appears to apply to these two chains. However, their performances differ: Chain 1 had lower levels, and Chain 2 recorded higher levels, of productivity, occupancy and room rates during the crisis. This may reflect their different demand management strategies.

In contrast, there are clear seasonal variations in the hotel's productivity, coinciding with seasonal variations in demand (see Jang, 2004). The highest and lowest levels of demand tend to be recorded in the late summer/early autumn and winter months respectively, which coincide with known natural and institutional determinants (Jeffrey \& Barden, 2001), such as school holidays and the timing of conference activities. There is also a sharp increase in productivity during the Christmas period, largely due to increased revenue in F\&B linked to seasonal festivities. Large advanced bookings for Christmas parties facilitate labour scheduling, thereby enhancing productivity.

This research also suggests that RevPAR and occupancy rate, variables which strongly reflect demand conditions, are major predictors of variations in productivity. These variables exert large marginal effects on productivity relative to labour management variables, 
accounting for high proportions of $\mathrm{R}^{2}$ values in the second step modelling. Of course, most hotels are not passive recipients of variable demand, and instead adopt dynamic approaches to demand management, but such practices lie outside the scope of this paper.

This is not to say that labour management practices have no impact on productivity: we concur with Sigala (2004) that both internal and external factors drive productivity. The inclusion of a range of labour management variables in the second step models added modest and sometimes marginal increases in the overall coefficients of determination. However, significant increases and decreases in productivity were observed depending on the type of flexible working analysed (see also Kappa et al., 1997; Li \& Prescott 2010; Nickson, 2010). In contrast, increasing the number of employees, as opposed to adopting more flexible working practices, at both establishment and departmental levels is associated with reduced hotel productivity (see Hu \& Cai, 2004).

As shown in the descriptive analysis, the mostly diverging effects of zero-contract and permanent labour on productivity at the scale of the establishment and both departments can partly be understood in terms of hourly wage differentials: rates are higher for permanentcontract than for zero-contract employees. However, the productivity implications also depend on the skills (generic and firm specific) of the two groups of employees. No direct measure of human capital is available in the data set, and the surrogate of wages cannot be utilised as labour cost is considered to be a different effect in this analysis, but an increase in training cost by one percent at the establishment level is associated with a 0.01 percent increase in productivity.

The negative effect of the number of employees on productivity in both chains for the establishment and both departments is another important finding (see Hu \& Cai 2004). It suggests limits have been reached in increasing productivity by further staff recruitment, perhaps reflecting the problem of increasing fixed costs in the face of variable demand. Some 
chains - such as those in this sample - have to maintain service levels (such as bars being open) associated with their brand standards at all times. Presumably, the minimum staffing required to deliver these services year-round is already in place, so that further increases in employees will depress productivity levels. 


\section{Conclusion}

A number of conclusions can be drawn from this micro-scale analysis of one of the central, but relatively ignored, sets of relationships in tourism economics: those between demand variations, labour productivity, and work flexibility practices.

First, the paper identifies that RevPAR (with an analogous measure for F\&B), reflecting overall demand variations, has the dominant relationship with productivity. This underlines the key roles played by marketing and revenue managers (Boffa \& Succurro, 2012), and the aim of increasing output while seeking to minimise or at least keep inputs unchanged (Jones \& Lockwood, 1989; Mill, 2008). For example, a dynamic pricing strategy can develop off- and on-peak pricing schemes to comply with demand variations, as well as drive market demand so as to lessen demand fluctuations (Capò Parrilla, et al., 2007). However, while productivity closely mirrors seasonal demand variations, it did not follow the pathway of GDP during the 2008+ crisis.

Although labour productivity is substantially explained by factors related to demand variations, this study also suggests that between 6-13 percent of the variation in hotel productivity is associated with effective utilization of labour resources. It does matter how firms respond to the double challenge of effectively controlling the productivity of labour inputs both when minimum levels of service provision are required at low points in demand, and when responding to peaks in demand. Accurately forecasting labour demand, in terms of both the quality and quantity of labour required in particular departments and then scheduling accordingly, is key to this, as is the type of work flexibility (the specific mix of numerical and functional) that is utilised. Guerrier and Lockwood (1989) suggested the importance of microlevels of forecasting estimation at the level of different types of departments. Even if the occupancy levels can be accurately predicted, there are still significant limits to the accuracy of predicted levels of activity in F\&B departments due to resident non-participation and non- 
resident guests. Moreover, possible improvements in productivity through labour management practices vary across establishments and departments, underlining the heterogeneity of productivity (Brown \& Dev, 2000; Wall \& Wood, 2005; Siebers et al., 2007). Managerial interventions need to be tailored (in terms of numerical $v$ functional flexibility, and the overall level of flexibility) and departmentally targeted.

These findings also suggest several topics for future research. While this paper focuses on financial measurement (gross revenue per hour of labour input) to estimate productivity, future research can explore more diverse approaches to estimating productivity in order to understand the complex and heterogeneous nature of productivity (Anderson et al., 1999). There is also a need to focus in more detail on labour flexibility and to examine how this varies across micro departments and different types of jobs, especially amongst those with supervisory roles (see also Dreyer \& Grønhaug, 2004). Additionally, like most econometric techniques employed in empirical investigations of economic problems, the fixed and random effects procedures have limitations. One shortcoming is that they may not account for endogeneity bias, and future studies could employ instrumental variable or GMM approaches with the econometric goal of correcting for this. 


\section{References}

Adib, A., \& Guerrier, Y. (2003). The interlocking of gender with nationality, race ethnicity and class: narratives of women in hotel work. Gender, Work and Organizations, 10, 413432.

Anderson, R. I., Fish, M., Xia, Y., \& Michello, F. (1999). Measuring efficiency in the hotel industry: A stochastic frontier approach. International Journal of Hospitality Management, 18, 45-57.

Andriotis, K. (2005). Seasonality in Crete: Problem or a way of life? Tourism Economics, 11(2), 207-224.

Atkinson, J. (1984). Manpower Strategies for Flexible Organizations. Personnel Management $16,28-31$.

Bagguley, P. (1990). Gender and labour flexibility in hotel and catering. The Service Industries Journal, 10(4), 737-747.

Baker, M \& Riley M (1994) New perspectives on productivity in hotels: some advances and new directions. International Journal of Hospitality Management, 13, 297-311.

Ball, R. M. (1989). Some aspects of tourism, seasonality and local labour market. Area, 21(1), $35-45$.

Bar-On, R. (1999). The measurement of seasonality and its economic impacts. Tourism Economics, 5, 437-458

Barros, C. P. (2005). Measuring efficiency in the hotel sector. Annals of Tourism Research, 32(2), 456-477

Baum T. (1998). Responding to seasonality in peripheral destinations. Tourism Intelligence Papers. British Tourist Authority, English Tourist Board: London; pp107-115.

Berg, P., Bosch, G. \& Charest, J. (2014). Working-time configurations: A framework for analyzing diversity across countries. Industrial \& Labor Relations Review, 67(3), 805-837.

Blake, A., Sinclair, M. T., \& Soria, J. A. C. (2006). Tourism productivity: Evidence from the United Kingdom. Annals of Tourism Research, 33(4), 1099-1120.

Bloom, N., \& van Reenen, J. (2007). Measuring and explaining management practices across firms and countries. Quarterly Journal of Economics, 122(4), 1341-1408.

Bloom, N., \& van Reenen, J. (2010). Why do management practices differ across firms and countries? The Journal of Economic Perspectives, 24(1), 203-224.

Boockmann, B., \& Hagen, T. (2001). The use of flexible working contracts in West Germany: Evidence from an establishment panel. ZEW Discussion Paper, no. 01-33, Mannheim.

Brown, J. R. \& Dev, C. S. (2000). Looking beyond RevPar: Productivity consequences of hotel strategies. Cornell Hotel and Restaurant Administration Quarterly, 40, 23-33.

Boffa, F., \& Succurro, M. (2012). The impact of search cost reduction on seasonality. Annals of Tourism Research, 39(2), 1176-1198.

Bronner, F., \& de Hoog, R. (2012). Economizing strategies during an economic crisis. Annals of Tourism Research, 39(2), 1048-1069.

Bryson A (2007). Temporary agency workers and workplace performance in the private sector. Mimeo, LSE.

Bull, P. J., \& Church, A. (1994). The geography of employment change in the hotel and catering industry of Great Britain in the 1980s: A sub regional perspective. Regional Studies, 28(1), 13-25.

Butler, B. W. (1994). Seasonality in tourism: Issues and problems. In Seaton et al. Tourism The State of the Art, (pp. 332-339). Chichester: Wiley.

Capo, J. P, Riera, A. F., \& Rossello, J. N. (2007). Tourism and long-term growth. A Spanish perspective. Annals of Tourism Research, 34(3), 709-726. 
Capò Parrilla, J. C., Font, A. R., \& Nadal, J. R. (2007). Accommodation determinants of seasonal patterns. Annals of Tourism Research, 34(2), 422-436.

Chadwick, C., \& Cappelli, P. (2002). Functional or numerical flexibility: Which pays off for organizations? Discussion Paper, Institute for Labor and Industrial Relations, University of Illinoi.

Cuccia, T., \& Rizzo, I. (2011). Tourism seasonality in cultural destinations: Empirical evidence from Sicily. Tourism Management, 32, 589-595.

Deloitte (2009). How luxury has lost its lustre. Deloitte Executive Report. Spring/Autumn issue.

Dreyer, B., \& Grønhaug, K. (2004). Uncertainty, flexibility, and sustained competitive advantage. Journal of Business Research, 57(5), 484-494.

Eugenio-Martin, J. L., \& Campos-Soria, J. A. (2014). Economic crisis and tourism expenditure cutback decision. Annals of Tourism Research, 44, 53-73.

European Travel commission (2013). European Tourism 2013 - Trends \& Prospects. Quarterly Report-Q3/2013. Brussels, Belgium: ETC.

Fernandez-Morales, A., \& Mayorga-Toledano, M. C. (2008). Seasonal concentration of the hotel demand in Costa del Sol: A decomposition by nationalities. Tourism Management, 29, 940-949.

Grant, M., Human, B., \& Le Pelley, B. (1997). Seasonality. In Insights - Tourism Intelligence Papers (pp. 5-9). British Tourist Authority, English Tourist Board: London.

Gronroos, C. \& Ojasalo, K. (2004). Service productivity: Towards a conceptualization of the transformation of inputs into economic results in services. Journal of Business Research, 57, 414-423.

Guerrier, Y., \& Lockwood, A. (1989). Core and peripheral employees in hotel operations. Personnel Review, 18(1), $9-15$.

Guizzardi, A., \& Mazzocchi, M. (2010). Tourism demand for Italy and the business cycle. Tourism Management, 31, 367-377.

Gustavsson, S.O. (1984). Flexibility and productivity in complex production processes. International Journal of Production Research, 22(5), 801-808.

Hausman, J. A. (1978). Specification Tests in Econometrics. Econometrica, 46(6), 1251-1271.

Hellerstein, J., Neumark, D. \& Troske, K. (1999). Wages, productivity and worker

characteristics: evidence from plant level production functions and wage equations. Journal of Labor Economics, 17, 409-446.

Hempell, T., \& Zwick, T. (2005) Technology use, organizational flexibility and innovation: Evidence for Germany. ZEW Discussion Paper No. 05-57, Mannheim.

Highman, J., \& Hitch, T. (2002). Tourism, sport, and seasons: The challenges and potential of overcoming seasonality in the sport and tourism sectors. Tourism Management, 23, 175-185.

Higon, A. D., Bozkurt, O., Clegg, J., Grulis, I., Salis, S., Vasilakos, N., \& Williams, A. M. (2010). The determinants of retail productivity: A critical review of the evidence. International Journal of Management Reviews, 12(2), 201-217.

$\mathrm{Hu}$, B. A. and Cai, L. A. (2004). Hotel labour productivity assessment'. Journal of Travel and Tourism Marketing, 16 (2-3): 27-38.

Jang, S. S. (2004). Mitigating tourism seasonality: Quantitative approach. Annals of Tourism Research, 31(4), 819-836.

Jeffrey, D., \& Barden, R. (2001). An analysis of the nature, causes and marketing implications of seasonality in the occupancy performance of English hotels. In T. Baum, \& S.

Lundtorp (Eds.), Seasonality in tourism (pp. 119-140). Amsterdam: Pergamon.

Johns, N., Howcroft, B. \& Drake, L. (1997). The use of data envelopment analysis to monitor hotel productivity. Progress in Tourism and Hospitality Research, 3(2), 119-127. 
Jolliffe, L., \& Farnsworth, R. (2003). Seasonality in tourism employment: Human resource challenges. International Journal of Contemporary Hospitality Management, 15(6), 312-316.

Jones, P., \& A. Lockwood. (2002). The Management of Hotel Operations, London: Cengage. Jones, P., \& Robinson, P. (2012). Operation Management. Oxford: Oxford university press.

Kappa, M. M., Nitschke, A., \& Schappert, P. B. (1997). Managing Housekeeping Operations, The Educational Institute of the American Hotel and Motel Association: East Lansing, MI.

Kelliher, C. (1989). Flexibility in employment: Developments in the hospitality industry. International Journal of Hospitality Management, 8(2), 157-166.

Kilic, H., \& Okumus, F. (2005). Factors influencing productivity in small island hotels: Evidence from Northern Cyprus. International Journal of Contemporary Hospitality Management, 17(4), 315-331.

Kimes, S. E. (2004). Restaurant revenue management. Cornell Hotel and Restaurant Administration Quarterly, 45(1), 52-67.

Kleinknecht, A., Oostendorp, R. M., Pradhan, M. P., \& Naastepad, C. W. M. (2006). Flexible labour, firm performance and the Dutch job creation miracle. International Review of Applied Economics, 20(2), 171-187.

Koenig-Lewis, N., \& Bischoff, E. E. (2004). Analyzing seasonality in Welsh room occupancy data. Annals of Tourism Research, 31(2), 374-392.

Koenig-Lewis, N., \& Bischoff, (2005). Seasonality research: The state of the art. International Journal of Tourism Research, 7, 201-219.

Krakover, S. (2000). Partitioning seasonal employment in the hospitality industry. Tourism Management, 21, 461-471.

Lockwood, A., \& Bowen, A. (2004). Small business success. Hospitality Review, 6(2), 4248.

Lockwood, A., \& Guerrier, Y. (1989). Flexible working in the hospitality industry: Current strategies and future potential. International Journal of Contemporary Hospitality Management, 1(1), 11-16.

Li P., \& Prescott, D. (2010). Labour productivity in the Canadian tourism sector. Ottawa: Canadian Tourism Human Resource Council.

McMahon, F. (1994). Productivity in the hotel industry. In A. V. Seaton (Ed.), Tourism: The State of the Art. Chichester, England: Wiley, pp. 616-625.

Michie, J., \& Sheehan, M. (2001). Labour market flexibility, human resource management and corporate performance. British Journal of Management, 12, 287-306.

Mill, R. C. (2008) Managing labour productivity. In: P. Jones (ed.) Handbook of Hospitality Operations and IT. Oxford, UK: Butterworth Heinemann, pp. $269-294$.

Morikawa, M. (2012). Demand fluctuations and productivity of service industries. Economics Letters, 117, 256-258.

Morita, H. (2005). Multiskilling, Delegation, and Continuous Process Improvement: A Comparative Analysis of U.S.-Japanese Work Organizations. Economica, 72(285), 69-93.

Nadal, J. R., Font, A. R., \& Rossello, A. S. (2004). The economic determinants of seasonal patterns. Annals of Tourism Research, 31(3), 697-711.

Nickson D. (2010) Human Resource Management for the Hospitality and Tourism Industries. Burlington: Elsevier.

OECD (2001). Measuring Productivity: Measurement of Aggregate and Industry-Level Productivity Growth. Paris: OECD 2001.

Oulton, N., \& Sebastia-Barriel, M (2013). Long and short-term effects of the financial crisis 
on labour productivity, capital and output. CEP Discussion Paper no 1185, LSE.

Page, S., Song, H., \& Wu, D. C. (2012). Assessing the impacts of the global economic crisis and swine flu on inbound tourism demand in the United Kingdom. Journal of Travel Research, 51(2), 142-153.

Pan, C-M. (2007). Market demand variations, room capacity, and optimal hotel room rates. International Journal of Hospitality Management, 26, 748-753.

Papatheodorou, A., Rossello, J., \& Xiao, H. (2010). Global economic crisis and tourism: Consequences and perspectives. Journal of Travel Research, 49(1), 39-45.

Reynolds, D., \& Biel, D. (2007). Incorporating satisfaction measures into a restaurant productivity index. International Journal of Hospitality Management, 26(2), 352-361.

Rust, R. T., \& Huang, M-H. (2012). Optimizing service productivity. Journal of Marketing, $76,47-66$.

Sethi, A. K., \& Sethi, S. P. (1990). Flexibility in manufacturing: A survey. International Journal of Flexible Manufacturing Systems, 2(4), 289-328.

Sheldon, P., \& Dwyer, L. (2010). The global financial crisis and tourism: Perspectives of the academy. Journal of Travel Research, 49(1), 3-4.

Siebers, P.-O., Aickelin U., Battisti,G., Celia, H., Clegg, C., Fu, X., De Hoyos, R. \& IonaA. (2007). Enhancing Productivity: The Role of Management Practices. London: Advanced Institute of Management, Working paper No. 65.

Sigala, M. (2004). Using the data envelopment analysis for measuring and benchmarking productivity in the hotel sector. Journal of Travel and Tourism Marketing, 16(2/3), 39 -60 .

Sill, B. T. (1991). Capacity management: Making your service delivery more productive. The Cornell Hotel and Restaurant Administration Quarterly, 31(4), 76-87.

Smeral, E. (2009). The impact of the financial and economic crisis on European tourism. Journal of Travel Research, 48(1), 3-13.

Smeral, E. (2010). Impacts of the world recession and economic crisis on tourism: Forecasts and potential risks. Journal of Travel Research, 49(1), 31-38.

Soltani, E., \& Wilkinson, A. (2010). What is happening to flexible workers in the supply chain partnerships between hotel housekeeping departments and their partner employment agencies? International Journal of Hospitality Management, 29, 108-119.

Song, H., Lin, S., Witt, S. F., \& Zhang, X. (2011). Impact of financial/economic crisis on demand for hotel rooms in Hong Kong. Tourism Management, 32, 172-186.

Spotts, D., \& Mahoney, E. (1993). Understanding the fall tourism market. Journal of Travel Research, 32(2), 3-15.

Wall, T. D., \& Wood, S. J. (2005). Romance of human resource management and business performance, and the case for big science. Human Relations, 58, 429-462.

Warhurst, C., \& Nickson, D. (2007) Employee experience of aesthetic labour in retail and hospitality. Work, Employment and Society, 21(1), 103-120.

White, M., Hill, S., Mills, C. \& Smeaton, D. (2004). Managing to Change? British Workplaces and the Future of Work. Basingstoke: Palgrave Macmillan.

Witt, C. A., \& Witt, S. F. (1989). Why productivity in the hotel sector is low. International Journal of Contemporary Hospitality Management, 1(2), 28-34.

Wong, K. K. F. (2004). Industry-specific and general environmental factors impacting on hotel employment. Asia Pacific Journal of Tourism Research, 9(1), 19-28.

Wooldridge, J. (2008). Introductory Econometrics: A Modern Approach. Thomson SouthWestern. 
Fig. 1. A proposed model of labour productivity strategies

Demand Management

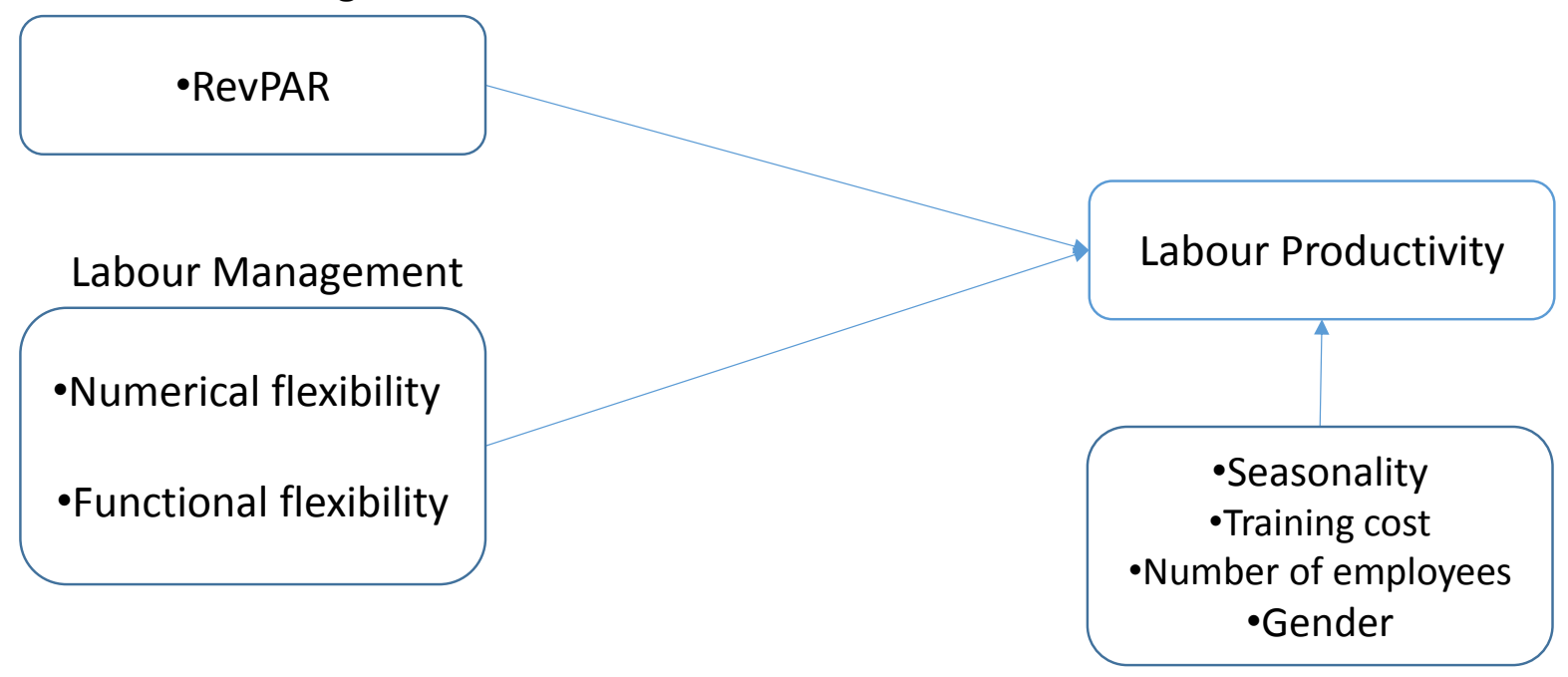

Control Variables 
Fig. 2a. Chain 1's Monthly Productivity and Occupancy Rate

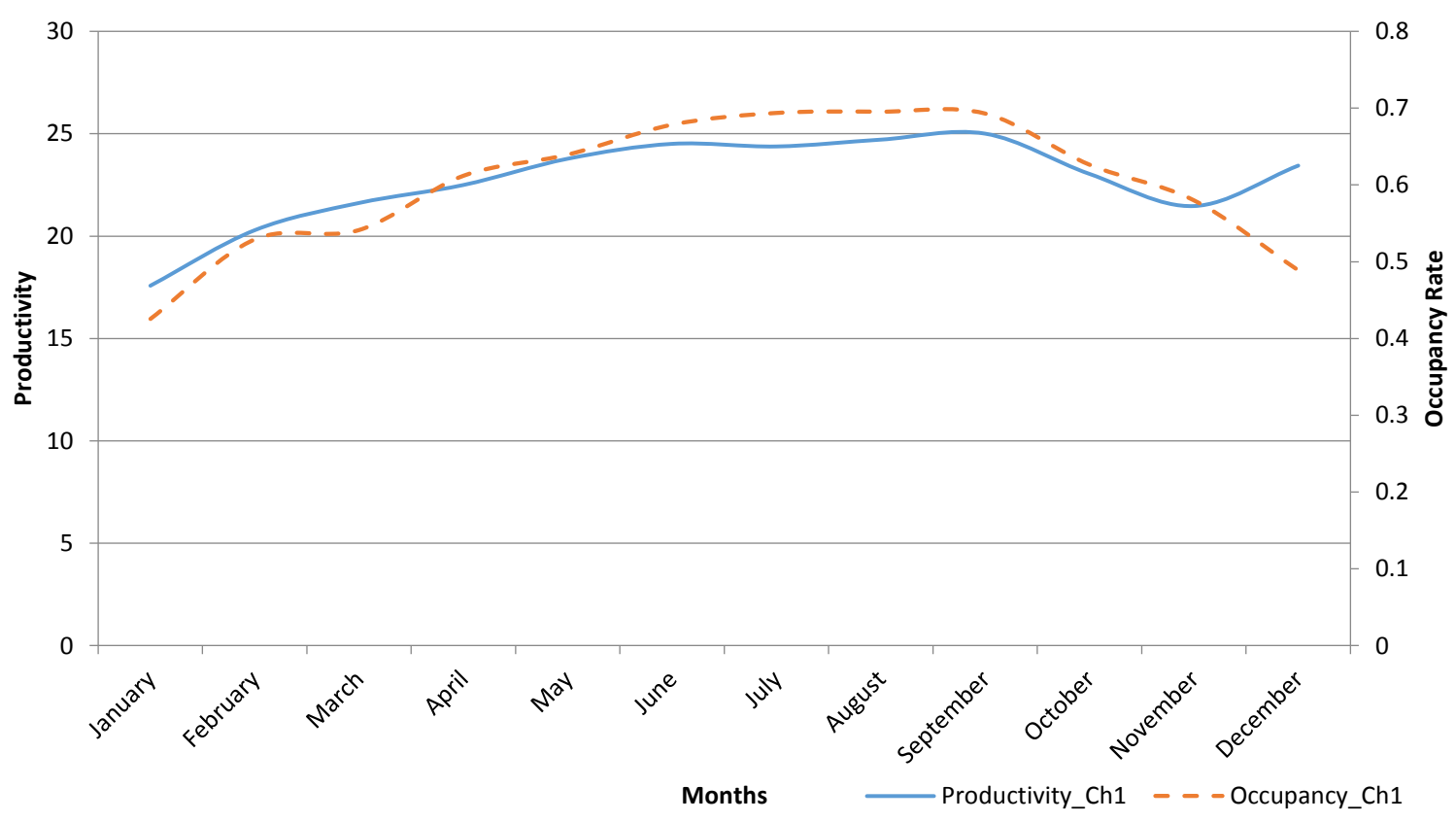


Fig. 2b. Chain 2's Monthly Productivity and Occupancy Rate

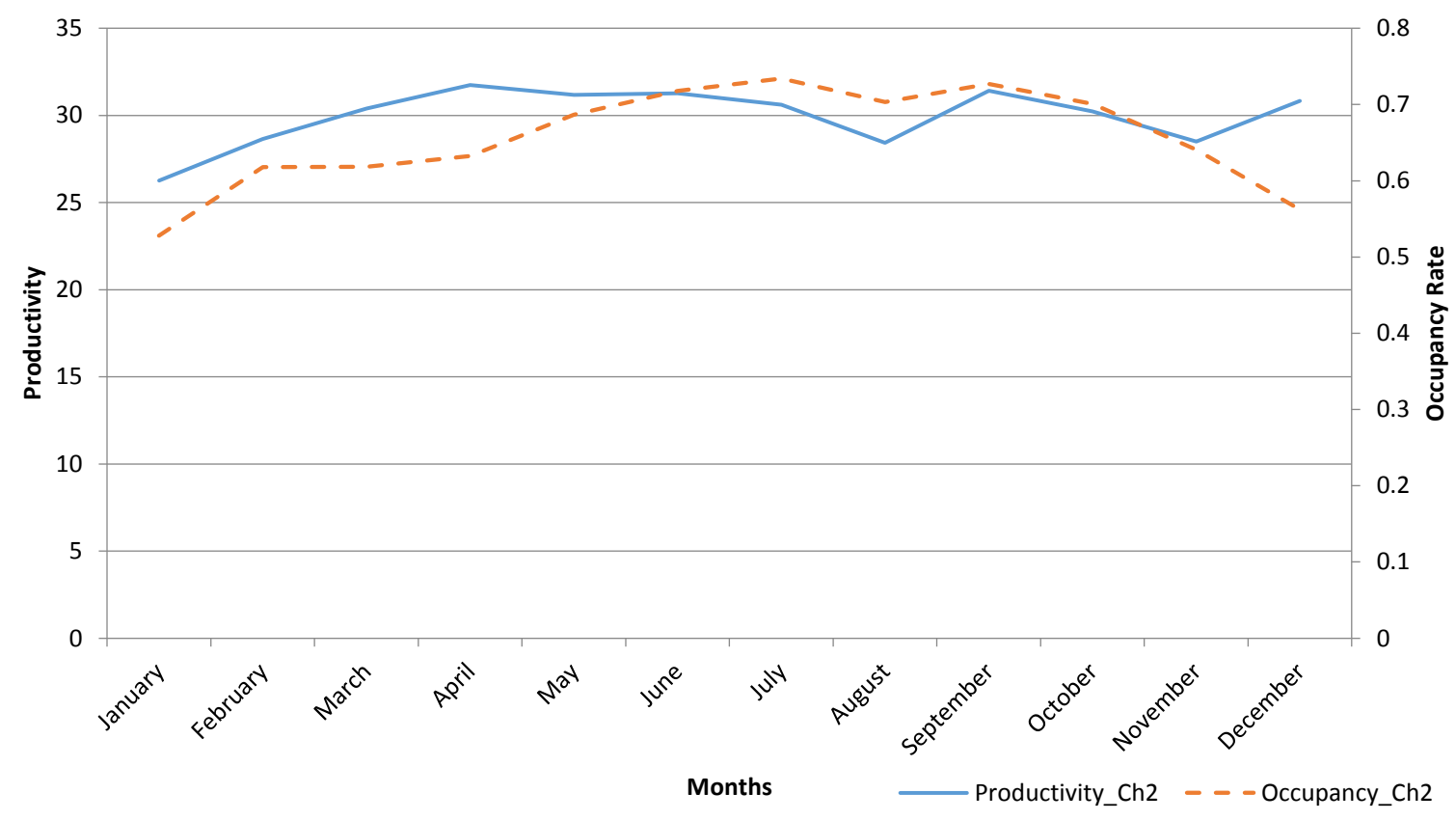


Fig. 3. Room rates of chain 1 and 2

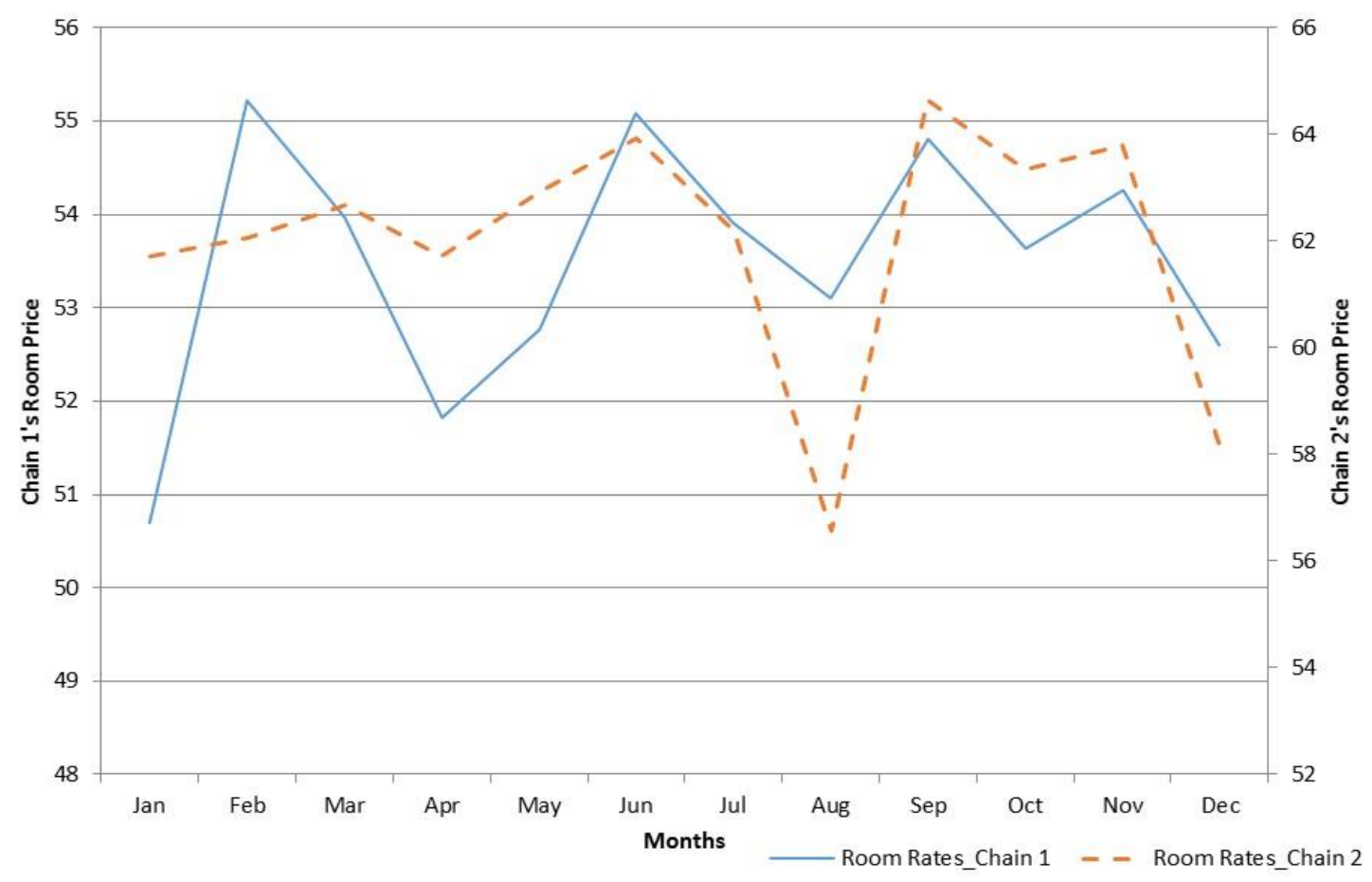


Fig. 4. Labour productivity of chains 1 and 2 with GDP growth

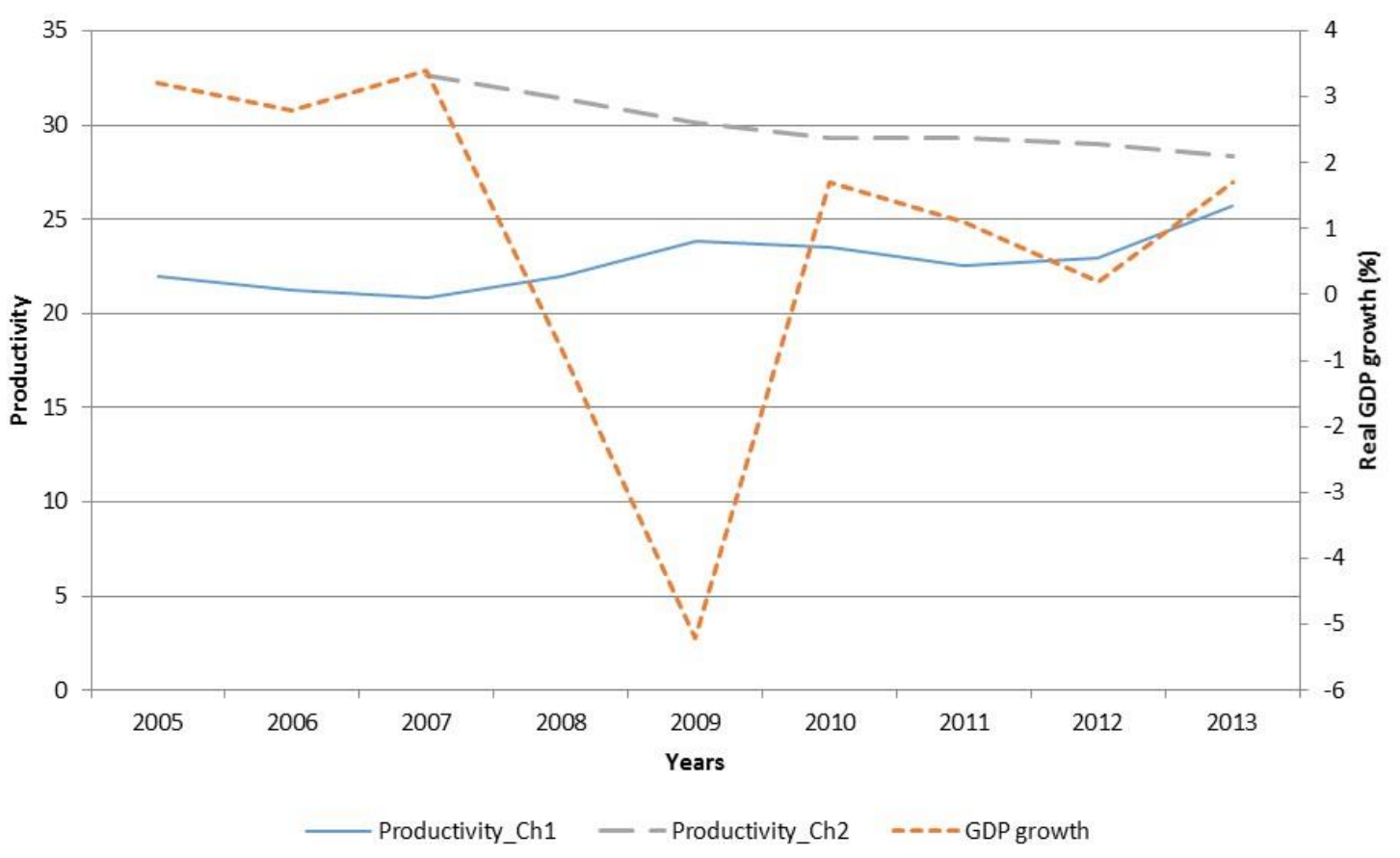


Fig. 5. Occupancy rates of chains 1 and 2 with GDP growth

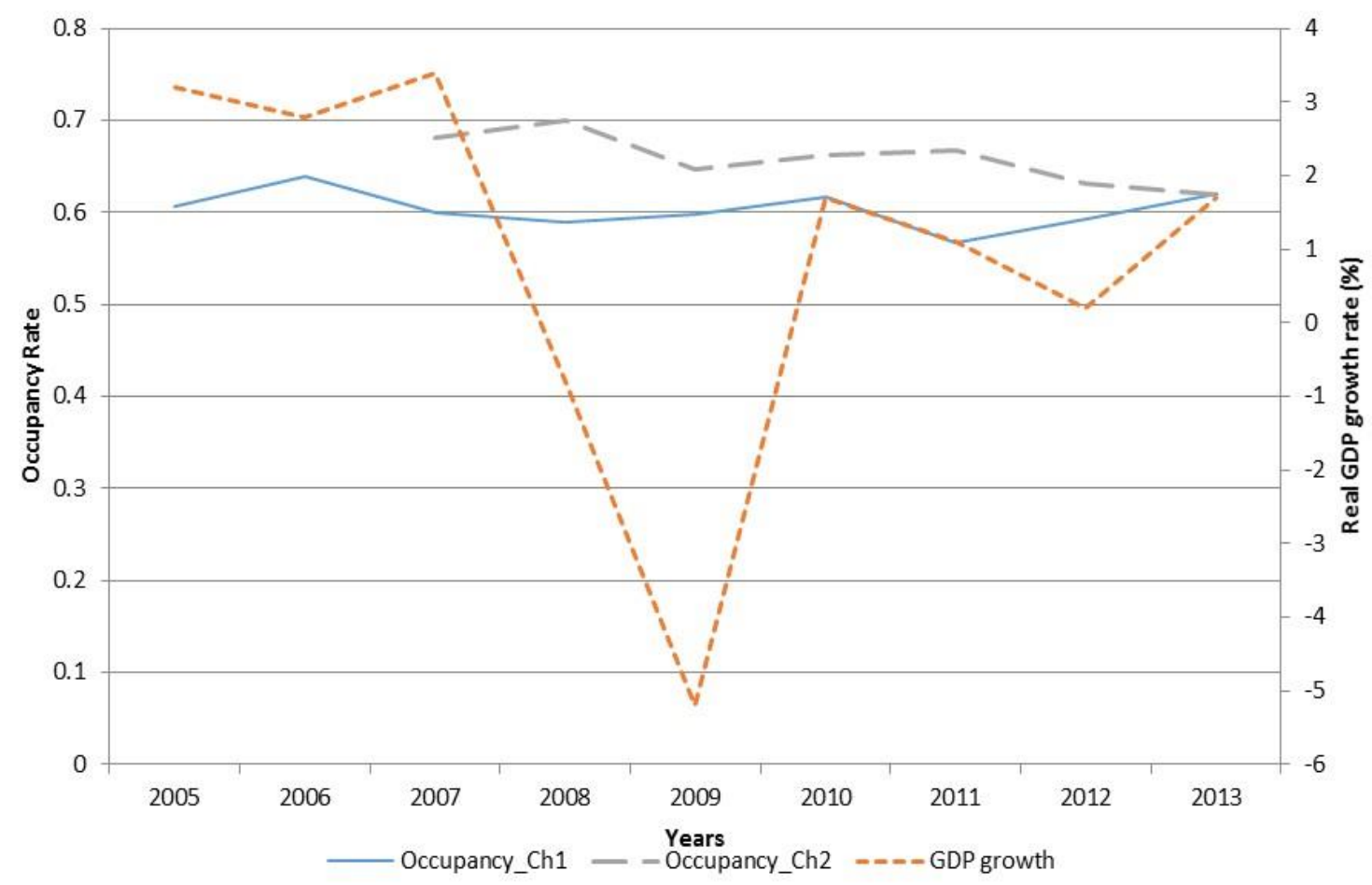


Fig. 6. Room rates of chains 1 and 2 with GDP growth

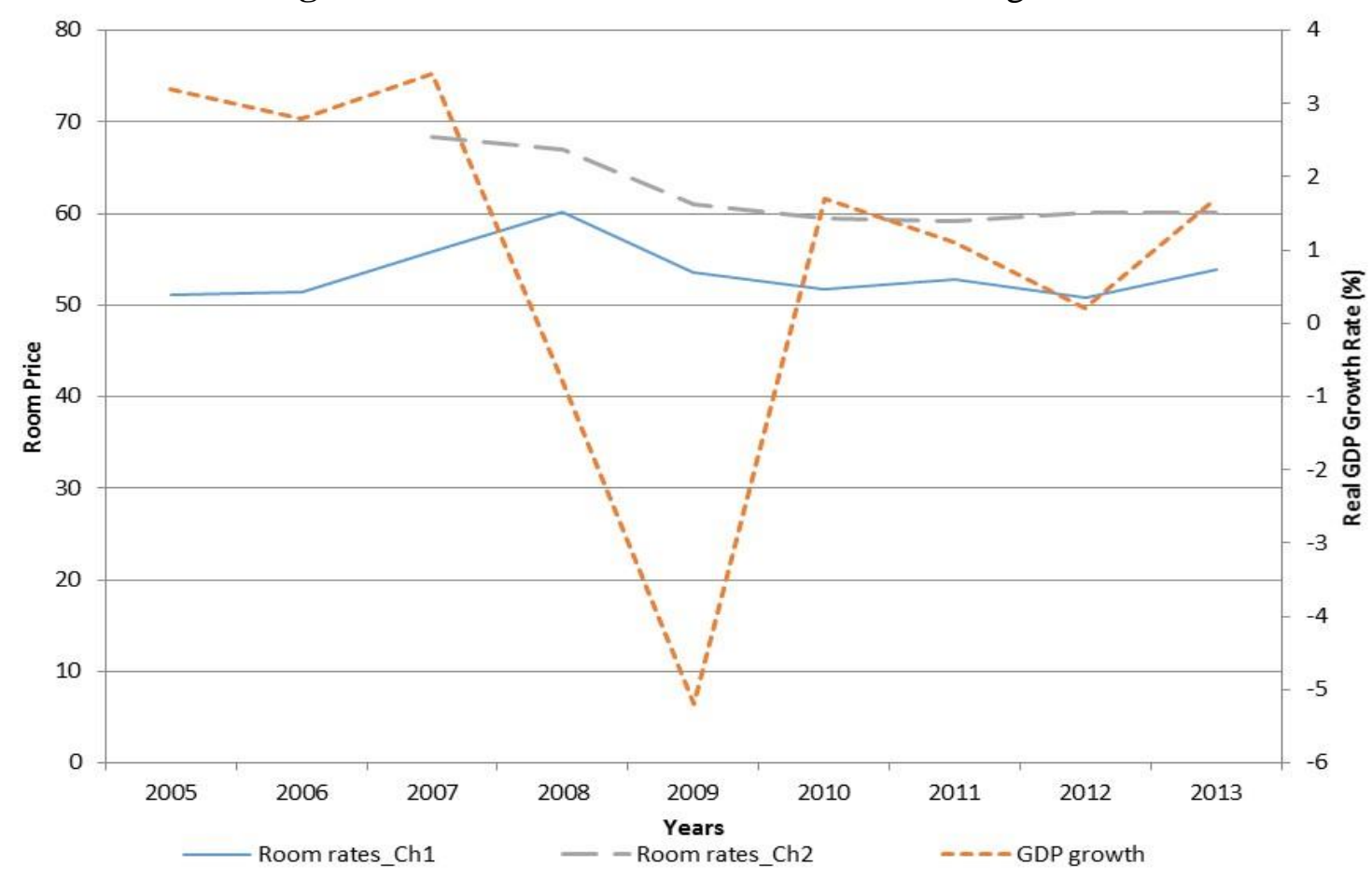


Table 1

Categorisation of Departments

\section{Rooms Department $\quad$ Food and Beverage $\quad$ Establishment Department}

\begin{tabular}{lll}
\hline Reception/concierge/switchboard & Restaurant & Rooms and Food and \\
Porters & Bar & Beverage plus residual \\
Nights/night porters & Room service & departments such as: \\
Room sales & Event food and bar & Conference, banqueting \\
Housekeeping & Cellar & and events \\
Room attendants/cleaning & Chefs and kitchen porters & Finance \\
Public area cleaning and linen & Leisure F\&B & Administration \\
porters & & Management \\
Laundry & & Maintenance \\
& & Leisure \\
& & \\
\hline
\end{tabular}


Table 2

Data summary

\begin{tabular}{|c|c|c|c|}
\hline \multirow[b]{2}{*}{ Variables } & Establishment & Rooms Dept. & F\&B Dept. \\
\hline & \multicolumn{3}{|c|}{ Chain 1} \\
\hline Financial productivity (revenue / labour hour) & 22.16 & 38.83 & 18.33 \\
\hline RevPAR & 32.475 & 32.475 & - \\
\hline Occupancy Rate & 0.603 & 0.603 & - \\
\hline Room Price $(£)$ & 53.52 & 53.52 & - \\
\hline F\&B Price $(\mathfrak{f})$ & 20.50 & - & 20.50 \\
\hline Numerical Flexibility & 0.247 & 0.247 & 0.289 \\
\hline Functional Flexibility & 0.096 & 0.043 & 0.027 \\
\hline Share of zero-contract employee hours in total hours & 0.123 & 0.126 & 0.184 \\
\hline Zero-contract employees’ wage cost per hour $(\mathfrak{f})$ & 5.16 & 5.60 & 4.98 \\
\hline Permanent-contract employees' wage cost per hour $(£)$ & 7.43 & 6.36 & 5.97 \\
\hline Share of female hours in total hours & 0.492 & 0.687 & 0.338 \\
\hline Female labour cost per hour $(\mathfrak{f})$ & 6.75 & 6.182 & 5.35 \\
\hline Male labour cost per hour $(\mathfrak{f})$ & 7.35 & 6.44 & 5.94 \\
\hline Training cost $(£)$ & 2912.15 & 1145.71 & 1631.07 \\
\hline \multirow[t]{2}{*}{ Number of employees } & 72 & 25 & 40 \\
\hline & \multicolumn{3}{|c|}{ Chain 2} \\
\hline Financial productivity (revenue / labour hour) & 27.88 & 48.64 & 26.95 \\
\hline RevPAR & 41.013 & 41.013 & - \\
\hline Occupancy Rate & 0.659 & 0.659 & - \\
\hline Room Price $(\mathfrak{f})$ & 62.02 & 62.02 & - \\
\hline F\&B Price $(\mathfrak{f})$ & 17.60 & - & 17.60 \\
\hline Numerical Flexibility & 0.235 & 0.217 & 0.277 \\
\hline Functional Flexibility & 0.071 & 0.018 & 0.032 \\
\hline Share of zero-contract employee hours in total hours & 0.235 & 0.216 & 0.323 \\
\hline Zero-contract employees’ wage cost per hour $(\mathfrak{f})$ & 5.55 & 5.76 & 5.42 \\
\hline Permanent-contract employees' wage cost per hour $(\mathfrak{f})$ & 8.85 & 7.13 & 6.89 \\
\hline Share of female hours in total hours & 0.537 & 0.676 & 0.384 \\
\hline Female labour cost per hour $(\mathfrak{f})$ & 7.26 & 6.36 & 5.77 \\
\hline Male labour cost per hour $(\mathfrak{£})$ & 8.13 & 7.01 & 6.61 \\
\hline Number of employees & 102 & 33 & 39 \\
\hline
\end{tabular}


Table 3

Results of fixed and random effects regression models: Establishments

Dependent Variables $^{1}$

[1a] InProd_Chain 1 [1b] InProd_Chain 2

Explanatory Variables

Estimated Coefficients Estimated Coefficients

\section{First Step}

\begin{tabular}{lcc} 
lnRevPAR & $0.6843 *(0.0318)$ & $0.6418 *(0.0607)$ \\
Constant & $0.7293 *(0.1102)$ & $0.9472 *(0.2252)$ \\
\hline Observations & 2,480 & 1,424 \\
Groups (hotels) & 25 & 18 \\
Adjusted R & 0.7348 & 0.6774 \\
\hline
\end{tabular}

\section{Second Step}

lnRevPAR

$0.8148 *(0.0456)$

$0.8853 *(0.0306)$

lnNumerical Flexibility

$0.2340 *(0.0564)$

$0.0438 * * *(0.0233)$

lnFunctional flexibility index

$0.0294 *(0.0108)$

$-0.0089(0.0056)$

lnShare of zero-contract hours in total hours

$0.0214 *(0.0034)$

$0.0278 *(0.0061)-$

[lnShare of permanent-contract hours in total hours]

$[-0.3638 *(0.0558)]$

$-0.0121(0.0325)$

lnShare of female hours in total hours

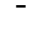

$[-0.0151(0.0274)]$

lnTraining cost

$0.0055^{* *}(0.0026)$

lnNumber of employees

Month dummies

$-0.5693 *(0.0439)$

Yes

$-0.6374 *(0.0344)$

Constant

$3.1892 *(0.1646)$

Yes

Observations

2,031

24

$3.0845 *(0.1254)$

Groups (hotels)

0.0000

1,414

F-test

0.8276

Adjusted R ${ }^{2}$

${ }^{1}$ Dependent variable is financial productivity at the establishment.

$* p<0.05 ; * * p<0.01 ; * * * p<0.001$ 
Table 4

Results of fixed and random effects regression Models: Rooms department

Dependent Variables ${ }^{1}$

[1a] InProd_Chain 1 [1b] InProd_Chain 2

Explanatory Variables

Estimated Coefficients Estimated Coefficients

\section{First Step}

\begin{tabular}{lcc} 
lnRevPAR & $0.7652 *(0.0243)$ & $0.7079 *(0.0461)$ \\
Constant & $0.9822 *(0.0843)$ & $1.2517 *(0.1713)$ \\
\hline Observations & 2,480 & 1,424 \\
Groups (hotels) & 25 & 18 \\
Adjusted R & 0.8017 & 0.7957 \\
\hline
\end{tabular}

$\operatorname{lnRevPAR}$

lnNumerical Flexibility
$0.8706 *(0.0364)$
$0.8687 *(0.0278)$
$0.0993 *(0.0311)$

lnFunctional flexibility index

$0.0142 *(0.0042)$

lnShare of zero-contract hours in total hours

$0.0014(0.0052)$

[InShare of permanent-contract hours in total hours]

$[-0.2939 *(0.0805)]$

$[-0.0077(0.0250)]$

lnShare of female hours in total hours

$-0.0763(0.0656)$

$0.1147 *(0.0345)$

[lnShare of male hours in total hours]

$[0.0062(0.0248)]$

$[-0.0660 *(0.0159)]$

lnTraining cost

$0.0012(0.0036)$

lnNumber of employees

Month dummies

$-0.4229 *(0.0398)$

Yes

$-0.4726 *(0.0421)$

Constant

$2.0568 *(0.1724)$

Yes

Observations

1,421

$2.5510 *(0.2273)$

Groups (hotels)

25

1,225

18

F-test

0.0000

0.0000

Adjusted R ${ }^{2}$

0.8677

0.9311

${ }^{1}$ Dependent variable is financial productivity in rooms department.

$* p<0.05 ; * * p<0.01 ; * * * p<0.001$ 
Table 5

Results of fixed and random effects regression models: Food and beverage department

Dependent Variables ${ }^{1}$

\section{[1a] InProd_Chain 1 [1b] InProd_Chain 2}

Explanatory Variables

Estimated Coefficients $\quad$ Estimated Coefficients

\section{First Step}

InOccupancy Rate

$\ln F \& B$ Price

$0.6817 *(0.0317)$

$0.7119 *(0.0817)$

Constant

$0.2363 *(0.0338)$

$0.7781 *(0.0409)$

Observations

$2.6251 *(0.0859)$

$1.3814 *(0.0959)$

Groups (hotels) 2,404

25

1,418

0.5843

18

Adjusted R ${ }^{2}$

0.7265

\begin{tabular}{|c|c|c|}
\hline InOccupancy Rate & $0.8272 *(0.0390)$ & $0.7509 *(0.0701)$ \\
\hline $\operatorname{lnF} \& B$ Price & $0.1232 *(0.0263)$ & $0.6827 *(0.0582)$ \\
\hline lnNumerical Flexibility & - & $0.2257 *(0.0709)-$ \\
\hline lnFunctional flexibility index & $0.0029(0.0048)$ & - \\
\hline InShare of zero-contract hours in total hours & $0.0198 *(0.0067)$ & $-0.0073(0.0123)$ \\
\hline [lnShare of permanent-contract hours in total hours] & {$[-0.1249 * *(0.0531)]$} & {$[0.0854 * * *(0.0463)]$} \\
\hline InShare of female hours in total hours & $0.0345(0.0252)-$ & $-0.0372(0.0303)$ \\
\hline [lnShare of male hours in total hours] & - & {$[0.0414(0.0483)]$} \\
\hline InTraining cost & $0.0128 *(0.0046)$ & - \\
\hline InNumber of employees & $-0.3669 *(0.0385)$ & $-0.3780 *(0.1066)$ \\
\hline Month dummies & Yes & Yes \\
\hline Constant & $4.3995 *(0.1739)$ & $3.3023 *(0.4783)$ \\
\hline Observations & 1,505 & 1,394 \\
\hline Groups (hotels) & 25 & 18 \\
\hline F-test & 0.0000 & 0.0000 \\
\hline Adjusted $\mathrm{R}^{2}$ & 0.7112 & 0.7569 \\
\hline
\end{tabular}

${ }^{1}$ Dependent variable is financial productivity in Food and Beverage department.

$* p<0.05 ; * * p<0.01 ; * * * p<0.001$ 